whether or not the soap was the real cause, I a third time employed the soap deliberately to see if the ekzema was due to it. I was in excellent health, and in about three weeks. I found the disease reestablished, so that I think the soap must be viewed as found guilty. Good white unscented curd soap is now my resource, and with no ill-effects.

Ekzema is always a distressing complaint even when affecting those in the most robust health. With those of bad constitution or lowered health, however, it seems to degenerate into bad or intractable skin diseases, so that probably this notice may not be deemed useless or uncalled for.

R. M.

\section{THE SCHOOL OF MILITARY ENGINEERING}

THERE are few educational establishments, in this country at any rate, that fulfil their object so aptly and so well, as the School of Military Engineering at Chatham. When we remember the many sciences and technical accomplishments with which the officers of the Royal Engineers are conversant, and the practical use that many of them are required to make of their acquirements, it is very obvious indeed that, to be successful, the system of education must be a most complete and substantial one. It is, in truth, necessary that a man entering either of the scientific corps of the army-the Royal Artillery or Royal Engineers-should not only be intuitively quick and clever, so as to grapple with the multifarious subjects of study, but it is moreover quite as indis. pensable that he should be at the outset sufficiently strong and healthy to withstand the wear and tear of so much hard work. To become a Mr. Toots would, we fear, be the fate of many young gentlemen, were they passed through the Woolwich Academy, and into these departments of the Army, without first undergoing a rigid medical examination; for the severe and lengthy curriculum is such as would certainly jeopardise the health of any but the strongest constitutions. Commissions in the Royal Artillery and Royal Engineers, be it remembered, have for many years past been obtainable only by open competition, the successful candidates being admitted into the Royal Military Academy, whence they are passed into the Army when found properly qualified. But to compete successfully for admission to the Academy in the first instance, involves already a knowledge of mathematics, of experimental and applied sciences, of languages, and other subjects too numerous to detail, such indeed as is scarcely possessed by other well-educated professional men; and this, bear in mind, is but the starting-point of the scientific soldier's education. At the Academy, where the course of special instruction sometimes continues for three years, he has to pass from a lower to an upper section, and when successfully through the examinations that beset him at every turn, he receives his commission in a provisional sort of way only. The successful Academicians highest on the list are sent to Chatham, to commence instruction in their duties as Royal Engineers, while the remainder complete their education at Woolwich and Shoeburyness, as lieutenants in the Royal Artillery. And if, after all this, there are yet dissatisfied spirits, who still exhibit a craving for more, then there is the staff college, the advanced class, instruction certificates, and other ends to be attained, enough in all conscience to satisfy the most ambitious.

It is to the School of Military Engineering that the young lieutenants of Engineers are sent for instruction in their various duties, and it is only after passing through a two years' course at this establishment that their commissions are actually secured to them. The professors, or instructors, as they are termed, are all officers of some years' standing in the corps, appointed by reason of their intimate acquaintance with the special subjects that they teach. These subjects are not only very various, but are, moreover, always increasing, as our system of warfare continually improves. Thus, besides the subjects of surveying, construction, estimating, fortifications, telegraphy, and other more ordinary, though not less practical, matters, there have been added of late years, chemistry, photography, army signalling, torpedo service, \&c., all of which the Royal Engineer must know something about:

It is evident that mere theoretical instruction in matters like these would be of little use to men who occupy such practical appointments as are filled by most Engineer officers, and it is in this respect that the School of Military Engineering may claim superiority over kindred establishments. The studies, workshops, laboratories, and demonstrating. schools are of the most complete description, while the outworks and broken ground upon the Chatham lines and around the Brompton Barracks afford ample scope for the practical prosecution of those-studies which require a wide field of operations. It is this practical manner of going about one's duties that is calculated above all things to impart a thorough knowledge, and to inspire officers with true confidence in their abilities. Fortifications are designed, parallels drawn, mines prepared, bridges constructed, and other siege duties executed by the students themselves, to render them conversant with their duties practically as well as theoretically, while the appointment of temporary telegraph stations, the experimental application of explosive and torpedo charges, the actual exercise of signalling, both by day and night, impart experience which could not, of course, be gained by teaching or lectures in the schools.

But it is not only the officers who benefit by the Engineering School at Chatham. The non-commissioned officers, also, are required to attend instruction in field works, and can, indeed, if they desire it, pass through the entire system of study, a course imperative on all those desirous of promotion to "foremen of works," or to other similar positions. The sappers, too, are well acquainted with at least one trade, or calling, and as every company of Engineers is made up from a due proportion of all rades, it is obvious such a complete and intelligent body of men is ofttimes invaluable. Thus it is that, in the Colonies, in Australia, New Zealand, South Africa, ind other stations where detachments of Royal Engineers have been sent, their services have been found so truly valuable, every available talent being at once at hand for the carrying out of the engineering and other kindred duties necessary to be fulfilled in the occupation of a rough untravelled country. As an instance of this, we need point merely to the recent Abyssinian Campaign, which may justly be called a triumph of engineering-a gigantic piece of road-making in fact-rather than a victory over half-naked Africans; for here we have in something like six months, a rough tract of country surveyed and mapped out, four hundred miles of road made, aline of railway laid down, telegraph communication established, wells sunk, and all this over and above the transport of a large body of men and war material.

The subject of torpedoes and submarine mines was so recently discussed in these columns, that we need not again refer at any length to this latest military science just now under special investigation at Chatham. But before concluding these few remarks, we may make mention of some experiments upon an extensive scale that were not long since made with these terribly destructive machines. The charges were fired from the shore by means of electricity, the signal for their discharge being given from the distance almost of a mile; and to show the control and certainty exercisable in the system employed, there was, in one instance, a steamer made to pass harmlessly over one of the charges; which immediately afterwards, at a yiven signal, blew into framents a lainch following in tow 